\title{
Analisis Kesetaraan Gender dalam Bidang Ketenagakerjaan di Indonesia
}

\section{Analysis of Gender Equality on Employment in Indonesia}

\author{
Yeni Nuraeni $^{1}$, Ivan Lilin Suryono ${ }^{2}$ \\ ${ }^{1,2}$ Pusat Pengembangan Kebijakan Ketenagakerjaan, Kementerian Ketenagakerjaan, Indonesia \\ Email: yeninur@hotmail.com ${ }^{1}$,ivanlilins@yahoo.com ${ }^{2}$
}

Diterima: 03 Februari $2021 \quad$ Direvisi: 13 Juni 2021 Disetujui: 29 Juni 2021

DOI: 10.35967/njip.v20i1.134

\begin{abstract}
Abstrak: Permasalahan kesetaraan gender dalam bidang ketenagakerjaan masih banyak diperbincangkan di berbagai negara termasuk di Indonesia. Walaupun berbagai perlindungan telah diupayakan melalui produk-produk hukum internasional maupun nasional namun latar belakang budaya di suatu negara akan tetap berperan penting dalam upaya mencapai kesetaraan gender dalam bidang ketenagakerjaan. Tujuan penelitian ini menganalisis tingkat kesetaraan gender yang di Indonesia dan tantangan dalam mencapai kesetaraan gender di bidang ketenagakerjaan. Penelitian ini menggunakan analisis kualitatif dengan pengumpulan data primer melalui Focus Group Discussion (FGD). Hasil penelitian menunjukkan ketimpangan gender masih terjadi di Indonesia, namun seiring waktu ketimpangannya semakin mengecil, artinya kesempatan perempuan dan laki-laki semakin sama. Namun untuk meningkatkan kesetaraan gender masih ada beberapa hambatan secara institusi maupun sosial budaya, seperti ketiadaan kesepakatan antara pekerja perempuan dengan pengusaha terhadap kesetaraan gender di tempat kerja, peraturan kesetaraan gender masih kurang optimal ditegakkan, masih rendahnya kesadaran dari pekerja terhadap hak-haknya, serta rendahnya posisi tawar pekerja perempuan. Untuk itu, pemerintah perlu meningkatkan kesetaraan gender dengan meningkatkan penegakan hukum berkaitan dengan kesetaraan gender di bidang ketenagakerjaan dengan melibatkan koordinasi antara pemerintah pusat dan daerah dalam memperkuat sistem pengawasan ketenagakerjaan. Selain itu meningkatkan kesadaran atas hak kesetaraan gender angkatan kerja perempuan dan memberikan perlindungan sosial bagi pekerja perempuan di sektor informal.
\end{abstract}

Kata Kunci: Ketenagakerjaan, Pekerja Perempuan, Kesetaraan Gender, Kesenjangan Upah.

\begin{abstract}
The issue of gender equality in the field of employment is still widely discussed in various countries, including Indonesia. Although various protections have been sought through international and national legal products, the cultural background in a country will still play an important role in efforts to make gender equality in employment. The research aim is to analyze the level of gender equality on employment in Indonesia and the challenges in achieving gender equality in employment. This study uses qualitative analysis with primary data collection through Focus Group Discussion (FGD). The results of the study show that gender inequality still occurs in Indonesia, but over time the inequality is getting smaller, meaning that the opportunities for women and men are getting equal. However, to improve gender equality, there are still some institutional and sociocultural obstacles, such as the lack of agreement between women workers and employers on gender equality in the workplace, gender equality regulations are still not optimally enforced, workers' awareness of their rights is still low, and bargaining position of women workers. For this reason, the government needs to improve gender equality by increasing law enforcement related to gender equality in employment by involving coordination between the central and local governments in strengthening the labor inspection system. In addition to raising awareness of the gender equality rights of the female workforce and providing social protection for women workers in the informal sector.
\end{abstract}

Keywords: Employment, Female Worker, Gender Equality, Wage Gap. 


\section{Pendahuluan}

Konsep gender lahir akibat dari proses sosiologi dan budaya yang berkaitan dengan pembagian peranan dan kedudukan antara laki-laki dan perempuan dalam sebuah lingkungan masyarakat. Sebagian besar masyarakat menganggap peran sosial perempuan jauh tertinggal dan bersifat pasif dibandingkan dengan laki-laki dan hal ini tidak terjadi secara alamiah, tetapi akibat adanya konstruksi budaya (Qori, 2017). Budaya dan norma yang berlaku pada sebagian masyarakat Indonesia merupakan salah satu faktor yang menyebabkan pekerja perempuan lebih banyak dipekerjakan di sektor domestik dibandingkan di sektor publik, meskipun setiap perempuan Indonesia memiliki hak untuk memilih menjalani peran di sektor domestik maupun di sektor publik (KPPPA, 2018).

Pertumbuhan ekonomi meningkatkan kesempatan kerja tetapi tidak dapat dengan sendirinya mengurangi ketimpangan gender. Ketimpangan gender dalam bidang ketenagakerjaan masih merupakan isu dan permasalahan yang sering terjadi. Perbedaan antara laki-laki dan perempuan dalam penggunaan waktu di rumah, perbedaan tingkat pendidikan dan keterampilan, pembatasan sosial-budaya, segregasi sektoral dan pekerjaan, migrasi laki-laki, dan akses ke input produktif, semuanya mengarah pada ketimpangan gender dalam partisipasi pekerjaan yang layak (Mehrotra \& Sinha, 2017). Masih terjadinya ketimpangan gender di Indonesia khususnya di bidang ketenagakerjaan dapat ditunjukkan dengan lebih rendahnya akses perempuan terhadap pasar kerja dibandingkan dengan laki-laki dan kecenderungan perempuan bekerja mendapatkan upah yang lebih kecil dari pekerja laki-laki (Ari, 2017).

Data menunjukkan perbandingan Tingkat Partisipasi Angkatan Kerja (TPAK) antara perempuan dan laki-laki di Indonesia pada tahun 2017 adalah 50.89 : 82,51 (BPS,2017), hal ini menunjukkan TPAK perempuan jauh lebih rendah dibandingkan TPAK laki-laki. Hal ini berbanding terbalik dengan perbandingan jumlah penduduk perempuan dan laki yang berusia 15 tahun ke atas yaitu sebesar 96,7 Juta : 95,88 Juta (BPS,2017). Dari data-data tersebut dapat menunjukkan bahwa 47,24 juta perempuan usia produktif di Indonesia tidak aktif secara ekonomi (Scholastica, 2018). Berdasarkan studi yang dilakukan di sebagian besar negara berkembang, ketimpangan TPAK antara laki-laki dan perempuan sudah umum terjadi (Verick, 2018).

Salah satu penyebab masih rendah TPAK perempuan di Indonesia adalah faktor budaya dan norma yang masih berlaku di sebagian besar masyarakat yaitu peran tradisi lebih penting dari peran transisinya sehingga perempuan memiliki kecenderungan untuk tetap di rumah dan merasa bertanggung jawab untuk mengurus keluarga di rumah, sehingga menolak untuk memasuki pasar kerja. Perempuan bisa memiliki dua peran yaitu peran tradisi sebagai istri, ibu dan pengelola rumah tangga juga bisa memiliki peran transisi yaitu sebagai tenaga kerja, anggota masyarakat dan partisipan pembangunan (Dwi, 2017). Di sebagian wilayah Indonesia masih berlaku norma di mana penghargaan masyarakat terhadap perempuan yang mengurus anak dan suami di rumah lebih tinggi dibandingkan penghargaan yang diberikan terhadap perempuan yang memiliki karier di luar rumah (Azmi et al., 2012). Faktor lain yang tidak kalah penting pengaruhnya adalah masih rendahnya tingkat pendidikan dan keterampilan perempuan Indonesia untuk dapat memasuki pasar kerja serta masih banyak terjadi pernikahan dini (Scholastica, 2018).

Polemik lain yang banyak ditemukan adalah berkaitan dengan peran perempuan dalam penciptaan pendapatan. Perempuan mempunyai keterbatasan dalam perekonomian karena adanya diskriminasi gender dalam pasar tenaga kerja. ILO menunjukkan bahwa status dan formalitas pekerjaan berperan penting dalam terjadinya diskriminasi gender (ILO, 2013). Perempuan sering kali harus dihadapkan pada kebijakan yang bertentangan dengan peraturan kesetaraan gender ketika mereka memasuki dunia kerja. Diskriminasi sering kali masih dialami oleh pekerja perempuan di Indonesia baik itu berkaitan dengan proses rekrutmen pegawai sampai perbedaan dalam penerimaan upah antara pekerja laki-laki dan perempuan (KPPPA, 
2018). Dalam penerimaan upah, terjadi kesenjangan upah yang diterima oleh pekerja laki-laki dan perempuan yang memiliki jabatan, tingkat pendidikan dan tingkat keterampilan yang sama di perusahaan. Diskriminasi menjadi penyebab utama kesenjangan upah riil menurut gender, terutama pada penerima upah yang rendah. Fakta ini menunjukkan kurangnya penghargaan terhadap keterampilan perempuan di pasar kerja (Hennigusnia, 2014). Selain itu pekerja perempuan sulit untuk mencapai jabatan yang sama dengan laki-laki baik di negara berkembang seperti Indonesia maupun di negara maju (Kercheval et al., 2013).

Masih terjadinya diskriminasi gender dalam bidang ketenagakerjaan disebabkan masih terdapat keyakinan yang salah dalam masyarakat berhubungan dengan konsep marginalisasi, subordinasi, stereotip, violence dan beban kerja (Putri \& Fita, 2020). Berdasarkan banyaknya permasalahan kesetaraan gender di bidang ketenagakerjaan termasuk di Indonesia, maka penelitian ini bertujuan untuk memberi gambaran dan melakukan analisis terhadap sejauh mana kesetaraan gender di bidang ketenagakerjaan sudah ditegakkan, dan upaya apa yang harus dilakukan oleh pemerintah Indonesia untuk meningkatkan kesetaraan gender dalam bidang ketenagakerjaan.

\section{Metode}

Berdasarkan kategori dari jenis masalah yang dibahas, teknik yang digunakan serta pemilihan tempat dan waktu, penelitian ini dapat dikategorikan sebagai penelitian deskriptif di mana memiliki tujuan untuk mengungkapkan fenomena sosial yang terjadi di kalangan masyarakat perempuan Indonesia khususnya berkaitan dengan ketenagakerjaan. Penelitian ini menggunakan data yang bersumber dari data sekunder yang diperoleh dari proses penelaahan terhadap pustaka yang berkaitan dengan masalah yang dibahas. Adapun data primer yang digunakan dalam penelitian ini diperolah melalui mekanisme Focus Group Discussion (FGD).

\section{Hasil dan Pembahasan}

\section{a. TPAK Perempuan di Indonesia}

Konsep laki-laki yang wajib mencari nafkah dan perempuan mengurus rumah tangga, merupakan salah satu penyebab masih sangat rendahnya rasio TPAK perempuan Indonesia yaitu di bawah 1 dan lebih rendah dari TPAK laki-laki. Dari nilai rasio TPAK tersebut dapat menunjukkan masih belum tercapainya kesetaraan gender di bidang ketenagakerjaan antara lakilaki dan perempuan. Meskipun demikian perempuan bekerja yang bertujuan untuk memenuhi kebutuhan ekonomi terus meningkat walaupun proporsinya masih lebih kecil dibandingkan lakilaki. Perempuan terdorong untuk lebih dapat mengekspresikan dirinya dengan berpartisipasi di pasar kerja agar dapat membantu suami mendapatkan penghasilan tambahan (Dwi, 2017).

Secara global TPAK perempuan dari 1990 sampai 2010 mengalami stagnasi, dengan kondisi TPAK perempuan lebih rendah daripada TPAK laki-laki. Di mana hanya 50 persen dari jumlah perempuan didunia yang menjadi tenaga kerja mendapat upah, sedangkan pada laki-laki lebih dari 75 persen. Kondisi tersebut diduga adanya permintaan akan pekerja berketerampilan rendah berdampak pada TPAK secara umum (Schifman et al., 2019). Kondisi di Indonesia menunjukkan hal yang sama, selama dua dekade rata-rata TPAK laki-laki berada di sekitar 84 persen, sementara perempuan sekitar 50 persen. Pada 2018 menunjukkan 83 dari 100 laki-laki menjadi angkatan kerja, sementara perempuan hanya 52 dari 100 (KPPPA, 2019).

Perempuan yang menjadi pekerja rumah tangga dan tidak berbayar memberi peran signifikan terhadap rendahnya TPAK perempuan, karena mereka keluar dari angkatan kerja dan tidak termasuk dalam pengukuran TPAK (Schifman et al., 2019). Schaner \& Das, (2016) menemukan bahwa perempuan yang usia muda di daerah perkotaan mengalami peningkatan partisipasi angkatan kerja mereka dalam beberapa tahun terakhir, sebagian besar melalui pekerjaan berupah, sementara di daerah pedesaan telah mengurangi partisipasi angkatan kerja mereka, sebagian besar dengan memilih keluar dari pekerjaan informal yang tidak dibayar. 
Berdasarkan aspek ekonomi dan sosial budaya, stagnasi TPAK perempuan bukan berarti hal yang buruk. Menurut Oey dalam (Vibriyati, 2013), TPAK perempuan berbanding lurus dengan kemiskinan. TPAK perempuan yang menurun, menunjukkan adanya perbaikan kondisi ekonomi keluarga. Kebutuhan rumah tangga sudah terpenuhi dari pendapatan laki-laki sebagai kepala keluarga, sehingga perempuan tidak perlu masuk ke pasar kerja. Dengan kondisi ekonomi yang terpenuhi dan seiring meningkatnya pendidikannya maka perempuan memilih keluar dari angkatan kerja menjadi ibu rumah tangga. Hal ini sebagaimana disajikan pada Gambar 1.

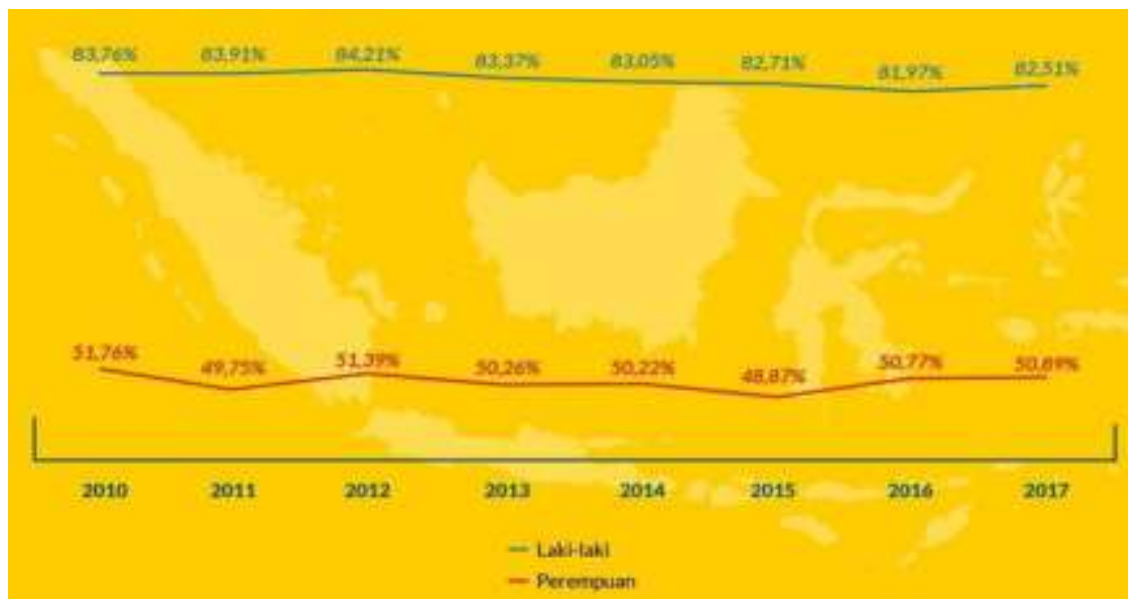

Gambar 1. Tingkat Partisipasi Angkatan Kerja Indonesia

Sumber : Scholastica (2018)

Keberhasilan Keluarga Berencana diduga juga dapat menurunkan TPAK perempuan. Hal ini terjadi karena perempuan yang memiliki jumlah anak yang banyak akan mengakibatkan banyaknya waktu yang harus dialokasikan untuk mengurus dan mendidik anak sehingga tidak dapat memasuki pasar kerja, demikian juga sebaliknya dengan memiliki jumlah anak yang sedikit, banyak besar peluang bagi perempuan untuk dapat memasuki pasar kerja (Vibriyati, 2013). Berdasarkan hasil Data Survei Demografi dan Kesehatan Indonesia (SDKI) dari tahun 2002 sampai tahun 2012, nilai TFR di Indonesia stagnan di angka 2,6 baru menurun pada survei SDKI tahun 2017 menjadi 2,4 yang artinya dalam masa reproduksi perempuan Indonesia dapat melahirkan rata-rata 2,4 anak. Gambar 1 menunjukkan perbandingan nilai TPAK perempuan dan laki-laki di Indonesia. Pada tahun 2017 terlihat nilai TPAK perempuan sedikit meningkat dengan menurunnya nilai TFR.

Indonesia dapat masuk dalam peringkat 10 besar dalam kesetaraan gender di antara negaranegara Asia. Kesetaraan gender menggunakan empat indikator yaitu ekonomi, pendidikan, kesehatan dan politik. Gambar 2 menunjukkan bahwa skor yang tinggi adalah bidang pendidikan dan kesehatan, yang berarti keterlibatan perempuan dalam menyelesaikan pendidikan tertinggi hampir sama dengan laki-laki. Hal yang sama terjadi pada bidang kesehatan, namun berbeda dengan bidang ekonomi yang menunjukkan kesetaraan gender dengan skor rendah. Terlebih lagi kesetaraan gender dalam bidang politik paling rendah, bahkan di bawah dari rata-rata global. Hal ini sebagaimana disajikan pada Gambar 2. 


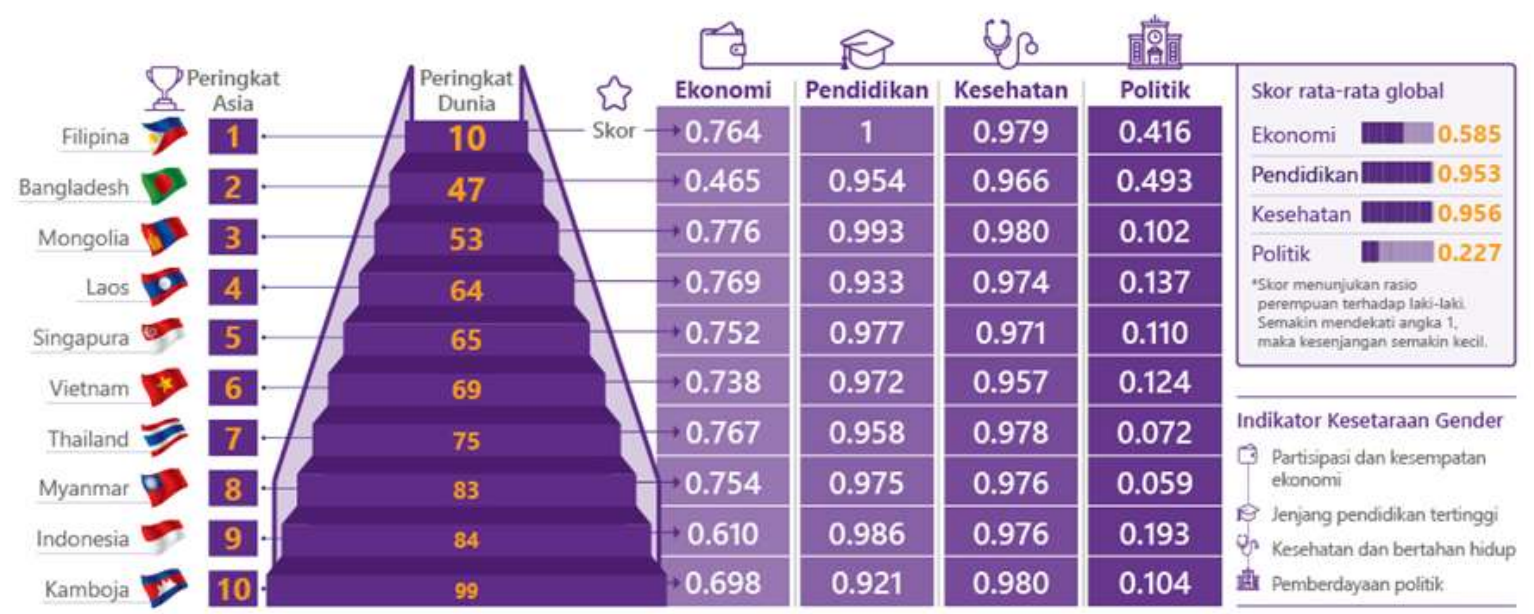

Gambar 2. Skor Kesetaraan Gender Negara-negara di Asia Tenggara Tahun 2017

Sumber : Katadata, (2018a)

\section{b. Kesenjangan Upah Antara Pekerja Perempuan dan Laki-laki}

Kesenjangan upah yang diterima laki-laki dan perempuan masih terjadi di Indonesia. Walaupun upah yang diterima oleh laki-laki dan perempuan memiliki kecenderungan meningkat dari tahun ke tahun karena didorong oleh regulasi kewajiban penerapan upah minimum, tetapi upah pekerja laki-laki lebih besar dibandingkan upah yang diterima pekerja perempuan. Dilihat dari rasio upah perempuan terhadap laki-laki terjadi peningkatan menuju kesetaraan gender.

Dengan adanya regulasi berkaitan dengan kewajiban perusahaan membayar upah minimum, mengakibatkan upah yang diterima oleh pekerja laki-laki dan perempuan memiliki kecenderungan terus meningkat dari tahun ke tahun. Walaupun secara umum upah yang diterima oleh perempuan terus meningkat dari tahun ke tahun tetapi tetap masih lebih rendah dari upah yang diterima oleh pekerja laki-laki, hal ini menunjukkan kesenjangan upah berdasarkan gender masih terjadi. Nilai gap upah laki-laki dan perempuan menunjukkan nilai yang terus meningkat. Gambar 3 menunjukkan kesetaraan gendar masih belum terjadi dalam hal pemberian upah bagi laki-laki dan perempuan. Selama periode 2015-2017 terlihat gap upah antara pekerja perempuan dan pekerja laki-laki semakin membesar. Pada Agustus 2015 gap masih sekitar 300 ribu, namun kondisi Agustus gapnya menjadi lebih dari 600 ribu rupiah. Hal ini sebagaimana disajikan pada Gambar 3.

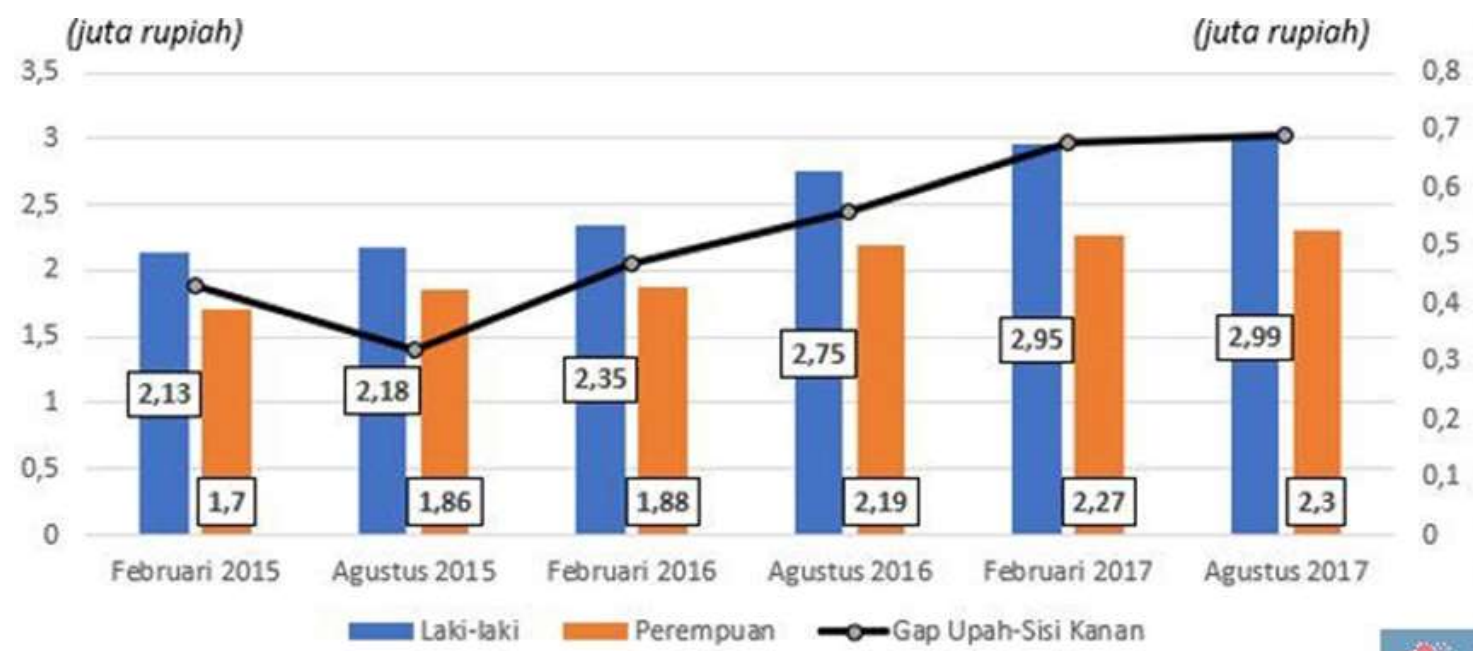

Gambar 3. Rata-rata Upah Per Bulan Buruh/Karyawan Berdasarkan Jenis Kelamin Sumber : Prakoswa, (2018) 
Sebagian besar pekerja perempuan bekerja di sektor informal serta tidak memiliki perlindungan sosial yang memadai sehingga rentan terhadap terjadinya pelanggaran hukum di tempat kerja berupa diskriminasi, kekerasan fisik, eksploitasi bahkan perdagangan manusia, dari segi upah pun pekerja perempuan hanya mendapat rata-rata 30 persen lebih rendah dibandingkan upah rata-rata pekerja laki-laki (Syaifuddin, 2018). Salah satu yang penyebab rendahnya upah yang diterima pekerja perempuan adalah karena sebagian besar pekerja perempuan hanya dapat mengisi lapangan kerja di sektor informal (Vibriyati, 2013). Perempuan mempunyai beberapa hambatan untuk berpindah dari pasar kerja informal ke pasar formal yaitu peran dan tanggung jawab kerumahtanggaan, status subordinat perempuan dalam relasi gender, dan sikap patriarki terhadap partisipasi perempuan dalam kehidupan ekonomi dan masyarakat (ILO, 2012). Dua fenomena yang masih terjadi adalah masih terjadi perbedaan rata-rata penghasilan yang didapatkan oleh pekerja perempuan yang lebih rendah dibandingkan penghasilan pekerja lakilaki dan masih terpilahnya berdasarkan gender berkaitan dengan jenis pekerjaan perempuan dan laki-laki.

Selain faktor pendidikan, yang berpengaruh pada besarnya upah yang diterima perempuan, faktor lainnya adalah kesempatan bagi pekerja perempuan untuk memilih lapangan kerja dan jenis pekerjaan yang tersedia serta memperoleh peluang dalam mendapatkan status pekerjaan. Sektor jasa perdagangan dan jasa kemasyarakatan, sosial dan perorangan merupakan lapangan kerja yang paling banyak terbuka bagi perempuan (Hakim, 2011). Adapun tenaga usaha perdagangan merupakan jenis pekerjaan yang paling banyak dilakukan oleh perempuan, Sedangkan status pekerjaan yang banyak disandang oleh pekerja perempuan adalah sebagai buruh/karyawan dan pekerja yang tidak dibayar (BPS, 2018). Lapangan pekerjaan, jenis pekerjaan serta status pekerjaan yang lebih banyak terbuka bagi pekerjaan perempuan itu pada umumnya memberikan standar upah yang relatif lebih kecil karena dianggap memiliki produktivitas yang rendah. Adapun bagi pekerja laki-laki lebih terbuka untuk bekerja di sektor yang padat modal dengan jabatan sebagai tenaga profesional, teknisi dan pimpinan yang tentunya memiliki standar upah yang lebih tinggi karena dianggap memiliki produktivitas yang tinggi juga. Perempuan yang memasuki pasar kerja pada umumnya jenjang kariernya tidak secepat laki-laki baik bagi mereka yang bekerja di sektor formal maupun informal, dalam pengembangan karier seorang karyawan perlu dipahami oleh semua pihak bahwa penerapan kesetaraan gender sangatlah penting (Ainun, 2018). Menurut World Bank (2012), dengan menghilangkan hambatan yang mencegah perempuan untuk bekerja di pekerjaan atau sektor tertentu akan memiliki efek mengurangi kesenjangan produktivitas antara pekerja laki-laki dan perempuan hingga sepertiga sampai setengahnya.

Data BPS tahun 2017 menunjukkan terdapat tiga sektor yang memberikan standar rata-rata upah/gaji tertinggi yaitu pertambangan sebesar 4,4 juta/bulan, sektor listrik, gas \& air sebesar Rp. 3,92 juta/bulan serta sektor jasa keuangan sebesar Rp. 3,87 juta/bulan. Ironisnya, jumlah pekerja perempuan pada sektor-sektor tersebut masih sedikit dibandingkan dengan pekerja lakilaki. Pada Gambar 4 menunjukkan pekerja perempuan di sektor pertambangan sebanyak 115.063 orang atau 8,9 persen dari pekerja laki-laki (1,28 juta orang). Pada sektor listrik, air, dan gas sebanyak 46.449 orang atau 13 persen dari pekerja laki-laki (347,42 ribu orang), sedangkan pada sektor jasa keuangan cukup banyak sebesar 1.091 .838 orang atau 41 persen dari pekerja laki-laki 2,66 juta orang). Secara jumlah banyak perempuan bekerja pada sektor perdagangan, restoran dan hotel, sektor pertanian dan sektor jasa kemasyarakatan. Pada sektor tersebut pekerja perempuan memperoleh upah yang rendah. Hal ini sebagaimana disajikan pada Gambar 4. 


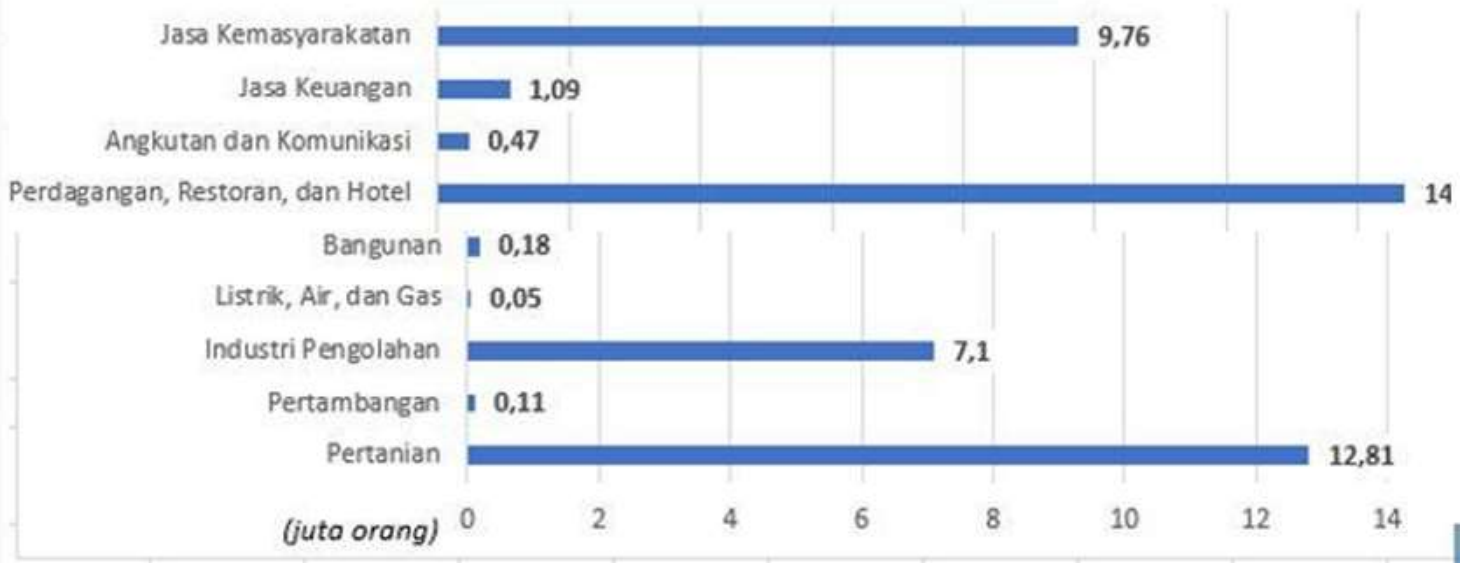

Gambar 4. Jumlah Tenaga Kerja Perempuan Berdasarkan 9 Sektor Lapangan Kerja Tahun 2017 Sumber : Prakoswa, (2018)

Perempuan dalam pasar kerja menjadi korban struktur ekonomi yang mengakibatkan perempuan harus masuk dalam sektor informal dengan upah yang rendah, ketidakjelasan aturan kerja, penggajian yang tidak proporsional, jaminan kesehatan yang kurang memadai, dan hukum tidak menyentuh pada sektor informal (Sofiani, 2017). Perempuan secara individu mempunyai keterbatasan dalam hal pendidikan, pengalaman dan ketrampilan kerja, kesempatan kerja serta faktor biologis menyebabkan perempuan hanya bisa memasuki lapangan pekerjaan yang berupah murah, sehingga kemungkinan besar mengalami eksploitasi (Sofiani, 2010). Perempuan pada umumnya dianggap lebih cocok untuk bekerja pada jenis pekerjaan yang membutuhkan kesabaran dan ketelatenan serta tidak membutuhkan tidak membutuhkan kekuatan fisik yang berat (Daulay, 2016). Keterbatasan pekerja perempuan untuk memperoleh peluang mendapat pekerjaan yang luas adalah terkait dengan keterbatasan modal yang dimiliki oleh pekerja perempuan. Peran serta masyarakat, lembaga swadaya masyarakat serta pemerintah sangatlah penting dalam rangka pengembangan diri bagi pekerja perempuan sehingga dapat terwujud keadilan dan kesetaraan gender di bidang ketenagakerjaan (Effendi \& Devi, 2018).

Peluang pasar tenaga kerja perempuan diera revolusi Industri 4.0 semakin mengkhawatirkan. Dengan makin tingginya sistem otomatisasi yang diterapkan oleh perusahaan, akan mengakibatkan hilangnya jenis pekerjaan yang bersifat administratif yang justru paling banyak dimasuki oleh pekerja perempuan. Di bidang sains, teknologi, teknik dan matematika (science, technology, engineering, and math/STEM) yang diperkirakan akan mengalami pertumbuhan sangat pesat dalam lima tahun mendatang khususnya dibidang komputer dan matematika justru kurang dapat terwakili oleh pekerja perempuan. Tingkat partisipasi perempuan Indonesia di masa menjalani STEM sebenarnya tergolong tinggi, namun dalam dunia kerja jumlah partisipasi perempuan yang bekerja di bidang STEM masih sedikit (Gambar 5). Perempuan tidak tertarik untuk bekerja di bidang STEM bisa disebabkan adanya anggapan lingkungan kerja yang akan banyak dominasi laki-laki serta adanya stereotip gender ketika mencari kerja. Hal ini sebagaimana disajikan pada Gambar 5. 

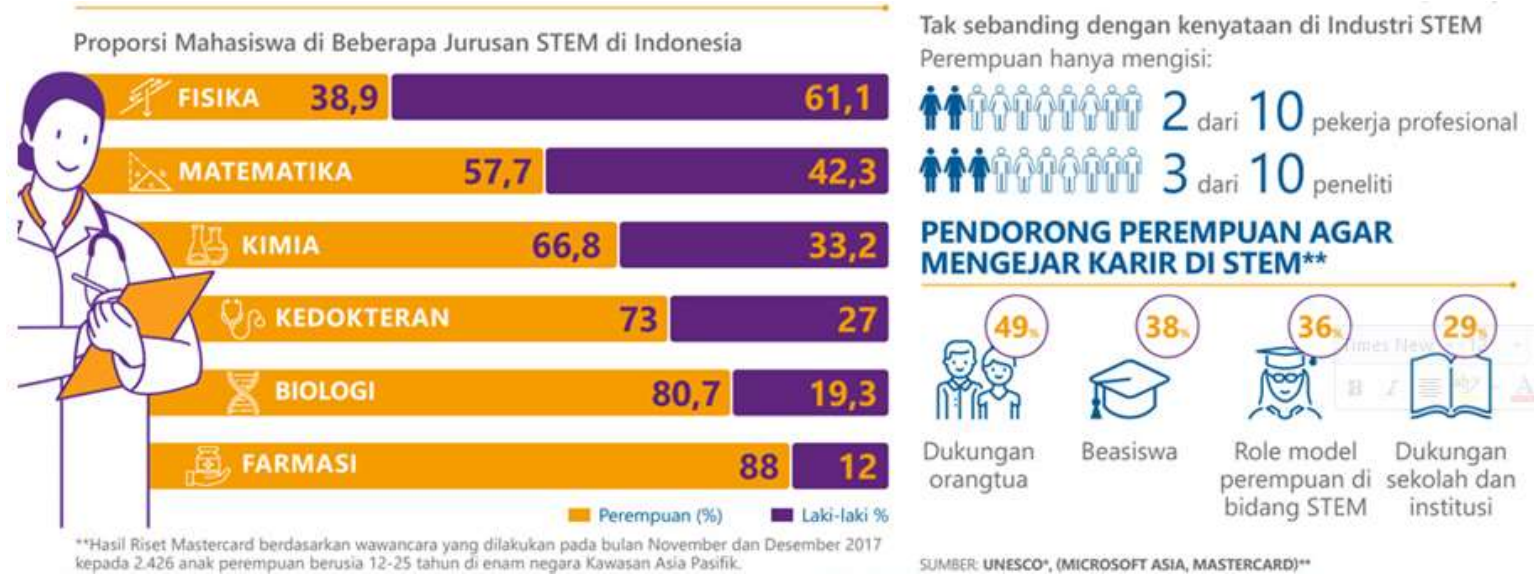

Gambar 5. Tingkat Partisipasi Perempuan dalam Pendidikan dan Dunia Kerja di Bidang STEM Sumber : Katadata, (2018b)

Guna mendorong partisipasi perempuan di bidang STEM peran orang tua dan pemerintah sangat penting, begitu pula dukungan sekolah dan institusi pendidikan untuk memberikan kesempatan lebih luas kepada perempuan melanjutkan pendidikannya di bidang STEM dan memberikan wawasan kesempatan kerja yang terbuka bagi perempuan di bidang STEM khususnya dalam menyambut era industri 4.0.

\section{c. Jumlah Tenaga Kerja Perempuan di luar negeri}

Di dorong oleh kondisi semakin terbatasnya kesempatan kerja di dalam negeri, minat untuk melakukan migrasi ke luar negeri dalam mencari pekerjaan semakin meningkat. Pendorong utama tenaga kerja di Indonesia untuk mencari pekerjaan di luar negeri, adalah untuk memperoleh penghasilan yang lebih tinggi dibandingkan kalau bekerja di dalam negeri. Pekerja Migran Indonesia (PMI) merupakan sebutan bagi angkatan kerja Indonesia yang memperoleh peluang bekerja di luar negeri. Data menunjukkan PMI laki-laki ternyata jumlahnya lebih sedikit dibandingkan PMI perempuan khususnya di sektor informal/ pengguna perseorangan (Santika et al., 2012). Sekitar 80 persen pekerja migran adalah perempuan, sebagian besar bekerja di perekonomian informal sebagai pekerja rumah tangga. Pekerja migran sebagian besar berasal dari keluarga miskin dengan latar belakang pendidikan yang rendah (hanya pendidikan dasar), bahkan beberapa tidak memiliki pendidikan formal atau pelatihan keterampilan (ILO, 2012).

Perlindungan hukum terhadap PMI khususnya perempuan masih kurang memadai. Payung hukum yang mengatur secara rinci berkaitan dengan aturan dan persyaratan pelaksanaan penempatan PMI ke negara tujuan belum tersedia. Hak-hak PMI perempuan yang bekerja khususnya di sektor informal belum terdapat dalam UU Ketenagakerjaan sehingga belum memiliki perlindungan hukum dalam menyelesaikan permasalahan di bidang ketenagakerjaan. Perumusan yang lebih jelas berkaitan dengan tujuan penempatan PMI perlu dilakukan dengan didukung oleh kebijakan di bidang ketenagakerjaan yang lebih responsif terhadap gender dalam penempatan PMI perempuan. Diperlukan upaya dari pihak pengguna maupun agen penyalur untuk mengurangi kemungkinan penyimpangan tindakan yang dapat dilakukan oleh berbagai pihak.

\section{d. Dasar Hukum Kesetaraan Gender di Bidang Ketenagakerjaan}

Pemerintah terus mendorong untuk mewujudkan kesetaraan gender melalui berbagai program maupun mengeluarkan produk-produk hukum dan melakukan ratifikasi terhadap produk hukum internasional. Salah satu program yang terus didorong oleh pemerintah adalah Percepatan Pengarusutamaan Gender (PUG) melalui Perencanaan dan Penganggaran yang Responsif Gender (PPRG). Di tingkat Global pemerintah Indonesia juga sudah melakukan komitmen global untuk 
upaya mewujudkan kesetaraan gender salah satunya dengan menghadiri Pertemuan Konferensi Perserikatan Bangsa-Bangsa (PBB) untuk Perempuan IV di Beijing tahun 1995 yang dihadiri 189 negara. Konferensi tersebut menyetujui pengaplikasian Strategi PUG di Perencanaan dan Penganggaran Pembangunan. Di tingkat Nasional telah dikeluarkan Instruksi Presiden No.9 Tahun 2000 Tentang Keharusan Melaksanakan PUG Di Perencanaan/Penganggaran Di Semua Sektor Pembangunan. Melalui Inpres ini pemerintah Indonesia berkomitmen untuk mematuhi kesepakatan internasional dalam hal melaksanakan PUG. Salah satu upaya untuk mewujudkan kesetaraan gender di bidang ketenagakerjaan adalah dengan memberikan perlindungan khusus kepada pekerja perempuan sesuai dengan kekhususan dan keistimewaan yang dimiliki oleh pekerja perempuan yang harus dipahami oleh perusahaan seperti pemberian cuti hamil dan melahirkan sesuai dengan kodrat perempuan. Selain memiliki kekhususan pekerja perempuan juga harus dilindungi dari perlakuan diskriminasi dalam hubungan kerja, pemberian upah, tunjangan dan jaminan sosial, kesempatan untuk mengembangkan diri melalui pelatihan serta mendapatkan kesempatan untuk promosi jabatan (Aulya, 2017).

Sidang umum PBB pada tahun 1979 mencetuskan pentingnya pengakuan terhadap hakhak perempuan dengan mengadopsi CEDAW (Convention on the Elimination of All Form of Discrimination Against Women). Sidang ini membuka jalan bagi negara-negara di seluruh dunia termasuk Indonesia untuk melakukan ratifikasi terutama setelah Indonesia meratifikasi Konvensi Penghapusan Segala Bentuk Diskriminasi Terhadap Perempuan dengan diterbitkannya UndangUndang Nomor 7 Tahun 1984.

UUD 1945 telah mengamanatkan kesamaan kedudukan setiap warga negara Indonesia dan menentang adanya diskriminasi yang tercantum pada Pasal 27. Pasal ini yang menjadi landasan bagi UU Ketenagakerjaan untuk mencantumkan pasal-pasal larangan diskriminasi terhadap pekerja perempuan dan perlindungannya. Perlindungan hukum tindakan diskriminasi terhadap pekerja perempuan sudah tercantum dalam UU No. 13 Tahun 2003 tentang Ketenagakerjaan pasal 6 yang mengatur larangan diskriminasi dalam aspek memperoleh pekerjaan dan jabatan antara pekerja laki-laki dan perempuan. Produk hukum lainnya yang berkaitan dengan kesetaraan gender di bidang ketenagakerjaan adalah Kepmenaker No. 224 tahun 2003 berkaitan yang mengatur Kewajiban Pengusaha Yang Mempekerjakan Pekerja/Buruh Perempuan Antara Pukul 23.00 Sampai Dengan Pukul 07.00, aturan yang harus dipatuhi antara lain pengusaha tidak boleh memperkerjakan perempuan yang kurang dari 18 tahun di malam hari begitu juga bagi wanita hamil. Perlindungan kesetaraan pemberian upah bagi pekerja diatur dalam Peraturan Pemerintah Republik Indonesia Nomor 36 Tahun 2021 Tentang Pengupahan Pasal 2 ayat 2 diatur bahwa Setiap pekerja/buruh berhak memperoleh perlakukan yang sama dalam penerapan sistem pengupahan tanpa diskriminasi. Selanjutnya pada ayat 3 mengatur bahwa setiap pekerja/buruh berhak memperoleh upah yang sama untuk pekerjaan yang sama nilainya. Perlindungan hukum bagi pekerja perempuan berkaitan dengan jam kerja, cuti masa haid, cuti hamil dan melahirkan serta hak menyusui anak pada waktu kerja telah diatur dalam UU Ketenagakerjaan No. 13 Tahun 2003 Pasal 76 Ayat (1), (2),(3) dan (4). Pemberian keringanan bagi pekerja perempuan yang tercantum dalam pasal dan ayat-ayat tersebut berdasarkan pertimbangan pentingnya peran perempuan dalam menjalankan kodratnya bereproduksi (Ngajulu, 2016).

Hak pekerja perempuan telah dijamin oleh berbagai peraturan, undang-undang maupun konvensi internasional, tetapi pada kenyataannya masih banyak hak pekerja perempuan yang belum dapat dipenuhi, hal ini disebabkan oleh faktor internal yaitu rendahnya tingkat pengetahuan dan pemahaman dari pekerja perempuan itu sendiri terhadap haknya, maupun faktor eksternal yang dapat berupa budaya patriarki, marginalisasi dalam bidang pekerjaan, konsep stereotip terhadap perempuan serta masih kurangnya sosialisasi (Sali, 2017). Peran pemerintah juga masih belum berjalan efektif dalam melakukan implementasi peraturan perundangundangan terkait perlindungan pekerja perempuan. Hal ini di tandai dengan belum kuatnya 
penerapan sanksi bagi pelanggar peraturan yang dilakukan oleh perusahaan terkait perlindungan hak-hak pekerja perempuan. Pemerintah melalui pengawas ketenagakerjaan harus melakukan usaha yang preventif dan represif, namun tindakan represif akan dilaksanakan secara tegas terhadap perusahaan yang secara sengaja melanggar atau perusahaan yang berkali-kali mendapat peringatan (Manik, 2013). Untuk dapat mengupayakan penegakan dan perlindungan hukum bagi pekerja perempuan pemerintah perlu meningkatkan kerja sama dengan pengusaha dan pekerja, serta melakukan pengawasan secara ketat terhadap pelaksanaan produk-produk hukum yang berlaku tentunya dengan tetap memperhatikan kondisi ekonomi, sosial, budaya, politik dan kultur berlaku pada setiap lingkungan masyarakat

\section{Kesimpulan}

Di era revolusi industri 4.0, kesenjangan gender khususnya di bidang ketenagakerjaan masih terjadi, baik di negara maju maupun di negara berkembang termasuk Indonesia. Terjadinya kesenjangan gender di dunia kerja dapat dipengaruhi oleh institusi pemberi kerja maupun karena dipengaruhi sosial budaya. Kesenjangan gender yang dipengaruhi oleh institusi karena masih ada anggapan bahwa tingkat pendidikan dan pengalaman kerja yang dimiliki oleh pekerja perempuan lebih rendah dari pekerja laki-laki, eksklusivitas pekerjaan tertentu yang dianggap kurang layak dimasuki oleh pekerja perempuan, serta stigma yang masih sering melekat bahwa perempuan kurang produktif dibandingkan pekerja laki-laki.

Adapun kesenjangan gender akibat kondisi kultur/sosial karena masih menganut konsep patriarki di beberapa daerah Indonesia, tuntutan kepada perempuan untuk mengasuh anak dan mengurus keluarga jauh lebih penting dibandingkan mencari nafkah, pola asuh orang tua terhadap anak perempuan, serta ekspektasi sosial untuk tidak masuk ke dunia kerja.

Pemerintah Indonesia sudah cukup memberikan upaya perlindungan tenaga kerja perempuan dan mengurangi kesenjangan gender melalui dengan melakukan ratifikasi hukum internasional dan membuat produk hukum nasional. Perlindungan yang diberikan pemerintah melingkupi keselamatan dan kesehatan kerja, kebebasan untuk berserikat dan berdemokrasi di tempat kerja, perlindungan terhadap diskriminasi dan perlindungan pemenuhan hak-hak dasar pekerja.

Ketiadaan kesepakatan antara pekerja perempuan dan pengusaha dalam pemenuhan hakhak perempuan merupakan salah satu hambatan dalam upaya memberikan perlindungan hukum terhadap pekerja perempuan, sehingga masih sering terjadi penyimpangan dari aturan yang berlaku. Kondisi ini semakin diperburuk dengan minimnya pemberian sanksi terhadap pelanggar peraturan perundangan. Selain itu, dari sisi pekerja perempuan tingkat kesadaran atas haknya yang masih rendah yang disebabkan karena faktor ekonomi yang lemahnya daya tawar pekerja perempuan terhadap pemberi kerja.

Upaya yang perlu dilakukan untuk mencapai kesetaraan gender di bidang ketenagakerjaan yaitu: Pertama, memprioritaskan adanya penegakan hukum yang berlaku berkaitan dengan kesetaraan gender di bidang ketenagakerjaan serta pemberian sanksi terhadap pelanggaran peraturan dan perundangan yang berlaku. Kedua, meningkatkan koordinasi antara pemerintah pusat dan daerah dalam rangka penegakan hukum untuk meningkatkan kesetaraan gender di bidang ketenagakerjaan. Ketiga, memperkuat sistem pengawasan agar dengan mengupayakan meningkatkan jumlah, kapasitas maupun kompetensi tenaga pengawas agar dapat melakukan penegakan hukum dan pemberian sanksi terhadap diskriminasi. Keempat, mengupayakan perlindungan sosial yang lebih intens untuk pekerja perempuan disektor informal yang lebih rentan terhadap pelanggaran kesetaraan gender. Kelima, meningkatkan kesadaran atas hak kesetaraan gender bagi calon pekerja perempuan secara dini sebelum memasuki pasar kerja dan bagi pekerja perempuan memperkuat pengetahuan akan hak-hak perempuan di dunia kerja. 
Nakhoda: Jurnal IImu Pemerintahan

Vol. 20 No. 01 Tahun 2021 Halaman 68-79

e-ISSN: 2656-5277 | p-ISSN: 1829-5827

\section{Daftar Pustaka}

Ainun, M. (2018). Penerapan Kesetaraan Gender Dalam Pengembangan Karir Karyawan (Studi Perbandingan Antara Bank Syariah dan Konvensional di Pekanbaru). Marwah: Jurnal Perempuan, Agama Dan Jender, 17(1), 80-95.

Ari, Y. (2017). Tenaga Kerja Wanita Dalam Perspektif Gender Di Nusa Tenggara Barat. Jurnal Al-Maiyyah, 10(1), 115-131.

Aulya, M. K. (2017). Perlindungan Dan Hak Pekerja Perempuan Di Bidang Ketenagakerjaan. Jurnal Al-Maiyyah, 10(1), 115-131.

Azmi, I. A. G., Ismail, S. H. S., \& Basir, S. A. (2012). Women Career Advancement in Public Service: A Study in Indonesia. Procedia - Social and Behavioral Sciences, 58, 298-306. https://doi.org/10.1016/j.sbspro.2012.09.1004

BPS. (2017). Keadaan Angkatan Kerja di Indonesia Agustus 2017. Badan Pusat Statistik.

BPS. (2018). Keadaan Angkatan Kerja di Indonesia Februari 2018. Badan Pusat Statistik.

Daulay, H. (2016). Buruh Perempuan Di Industri Manufaktur Suatu Kajian Dan Analisis Gender. Jurnal Wawasan, 11(3), 1-9.

Dwi, E. W. (2017). Peran Ganda Perempuan Dan Kesetaraan Gender. Aspirasi: Jurnal MasalahMasalah Sosial, 8(2), 207-222.

Effendi, P., \& Devi, R. (2018). Kesetaraan Gender Dalam Prespektif Undang-Undang Nomor 13 Tahun 2003 Tentang Ketenagakerjaan. Jurnal Pro Hukum, 7(2), 1-8.

Hakim, L. (2011). Perkembangan Tenaga Kerja Wanita Di Sektor Informal: Hasil Analisa Dan Proxy Data Sensus Penduduk. Jurnal Among Makarti, 4(7), 20-32.

Hennigusnia. (2014). Kesenjangan Upah Antar Jender Di Indonesia : Glass Ceiling Atau Sticky Floor? Jurnal Kependudukan Indonesia, 9(2), 83-96.

ILO. (2012). Labour and Social Trends in Indonesia 2011 Labour and Social Trends in Indonesia 2011. International Labour Organization. Jakarta.

ILO. (2013). Labour and Social Trends in Indonesia 2012: working for a sustainable and equitable economy. International Labour Organization. Jakarta.

Katadata, T. R. dan P. (2018a). Kesetaraan Gender, Indonesia Masuk 10 Besar di Asia. https://katadata.co.id/timpublikasikatadata/infografik/5e9a55d54ff52/kesetaraan-genderindonesia-masuk-10-besar-di-asia?

Katadata, T. R. dan P. (2018b). Partisipasi Perempuan dalam STEM Merosot Saat Masuk Dunia Kerja. https://katadata.co.id/timpublikasikatadata/infografik/5e9a55deb480f/partisipasiperempuan-dalam-stem-merosot-saat-masuk-dunia-kerja

Kercheval, J., Markowitz, D., Monson, K., \& Read, B. (2013). Perempuan dalam Kepemimpinan: Penelitian mengenai Hambatan terhadap Ketenagakerjaan dan Pekerjaan Yang Layak bagi Perempuan. International Labour Organization. Jakarta.

KPPPA. (2018). Pembangunan Manusia berbasis Gender 2018. Kementerian Pemberdayaan Perempuan dan Perlindungan Anak.

KPPPA. (2019). Profil Perempuan Indonesia 2019. Kementerian Pemberdayaan Perempuan dan Perlindungan Anak.

Manik, E. (2013). Implementasi Undang-Undang Nomor 13 Tahun 2003 Tentang Ketenagakerjaan (Kasus Perlindungan Hak Pekerja/Buruh Perempuan Pada Sektor Garmen Di Kota Semarang). Journal of Politic and Government Studies, 2(1), 21-31.

Mehrotra, S., \& Sinha, S. (2017). Explaining falling female employment during a high growth period. Economic and Political Weekly, 52(39), 54-62.

Ngajulu, P. (2016). Perlindungan Hukum Terhadap Tenaga Kerja Wanita Yang Bekerja Pada Malam Hari Di Pt. Swara Indah Riau Berdasarkan Undang-Undang Nomor 13 Tahun 2003 Tentang Ketenagakerjaan. JOM Fakultas Hukum, 3(2), 1-15.

Prakoswa, R. H. (2018). Para Perempuan, Ini Posisi Wanita dalam Ekonomi Indonesia. https://www.cnbcindonesia.com/lifestyle/20180309180650-33-6793/para-perempuan-ini- 
posisi-wanita-dalam-ekonomi-indonesia

Putri, D. A. F., \& Fita, N. F. (2020). Relevansi Kesetaraan Gender dan Peran Perempuan Bekerja terhadap Kesejahteraan Keluarga di Indonesia (Perspektif Ekonomi Islam). AL-MAIYYAH Media Transformasi Gender Dalam Paradigma Sosial Keagamaan, 13(1), 38-50.

Qori, K. (2017). Peran Ganda Perempuan pada Keluarga Masyarakat Petani: Kasus Istri Petani di kecamatan Merapi Selatan Kabupaten Lahat. Jurnal Kajian Gender Dan Anak, 12(2), 151162.

Sali, S. (2017). Pelindungan Hak Pekerja Perempuan dalam Perspektif Feminisme. Aspirasi: Jurnal Masalah-Masalah Sosial, 8(2), 207-222.

Santika, T., Hoerniasih, N., \& Nurhasanah, E. (2012). Pemberdayaan Perempuan Bagi Tenaga Kerja Wanita (TKW) Di Desa Gempol Kecamatan Jatisari Kabupaten Karawang. Majalah Ilmiah Solusi Unsika, 1-13.

Schaner, S., \& Das, S. (2016). Female Labor Force Participation in Asia: Indonesia Country Study. In ADB Economics Working Paper Series Female. Asian Development Bank. https://doi.org/10.2139/ssrn.2737842

Schifman, L., Oden, R., \& Koestner, C. (2019). Gender Wage Gap: Causes, Impacts, and Ways to Close the Gap. In W. Leal Filho, A. Azul, L. Brandli, P. Özuyar, \& T. Wall (Eds.), Gender Equality. Encyclopedia of the UN Sustainable Development Goals. (pp. 663-673). Springer, Cham. https://doi.org/10.1007/978-3-319-95687-9_50

Scholastica, G. (2018). Rerata Penghasilan Perempuan Masih Jauh di Bawah Gaji Laki-Laki. Tirto.Id.

Sofiani, T. (2010). Eksistensi Perempuan Pekerja Rumahan Dalam Konstelasi Relasi Gender. Muwazah, 2(1), 197-203.

Sofiani, T. (2017). Perlindungan Hukum Pekerja Perempuan Sektor Informal. Muwazah, 9(2), 9.

Syaifuddin, Z. (2018). Membincang Peran Ganda Perempuan Dalam Masyarakat Industri. Jurnal Jurisprudence, 8(2), 81-86.

Verick, S. (2018). Female Labor Force Participation in Developing Countries. IZA World of Labor.

Vibriyati, D. (2013). Ketimpangan Gender Dalam Patisipasi Ekonomi : Analisis Data Sakernas 1980 - 2013. Jurnal Kependudukan Indonesia, 8(1), 1-16.

World Bank. (2012). Gender Equality and Development. World Bank. 